\title{
Announcement
}

\section{THE RANK PRIZE FUNDS}

\section{Vacation Studentships}

Following the Pilot Scheme in 1996, The Rank Prize Funds will again be offering a number of vacation studentships commencing in the Summer of 1997 . A total grant of $£ 1,200$ per student ( $£ 150$ per week for 8 weeks) will be available for students to assist in research projects in the fields of human nutrition, animal nutrition and crop husbandry. Supervisors already working on appropriate projects should apply to the Funds' Office at 45, St. Mary's Road, Ditton Hill, Surrey, KT6 $5 \mathrm{HB}$ for further information. 